The candidate reader is questioned as to his or her mother tongue and is then given the oath to read aloud in the appropriate language. Afrikaans-sprekendes het dus geen verskoning dat hulle nie geweet het dat hulle nie vlamme onder Bodley se boeke mag inbring nie.

\title{
Die stand van die Klassieke in Engeland
}

Tydens 'n onlangse kort studiebesoek het ek die volgende waargeneem:

Deur aggressiewe bemarking, en deur meer gebruik te maak van die by ons bekende "double major"-sisteem (tot nog toe grotendeels ongehoord in Engeland) kry die Universiteit Leeds se School of Classics dit reg om ongeveer 80 studente jaarliks voor te berei vir 'n drie- of in sommige gevalle vierjarige honneurskursus in die klassieke. Die Departement Klassieke se kleurbrosjure is aantreklik en gee 'n duidelike uiteensetting van keuses, asook elke dosent se spesialiteitsrigting.

By die Universiteit Leeds se ope dag, wat op die dag na die Leeds International Latin Seminar gehou is, het die Departement Klassieke sy rekenaarfasiliteite ten toon gestel. Studente, onder leiding van dr. Robert Maltby, het uit Apicius se kookboek "Romeinse" versnaperings voorberei en aan die publiek gebied. Dit was opvallend dat selfs ouers met kinders in die laerskool die ope dag bygewoon het. Dit sorg vir vroegtydige reklame vir wat die Departement aanbied. Die hou van so 'n universitêre, of fakultêre, of selfs departementele ope dag is ' $n$ navolgingswaardige idee.

By die Universiteit Oxford is die klassieke nog stewig gewortel en die sowat 50 lessenaars van die Klassieke leeskamer in die Bodleian was byna heeltyd ten volle beset. Dit is natuurlik ook ' $n$ uitvloeisel van die tutoriale stelsel, waar studente grootliks van selfstudie gebruik maak, en weekliks geskrewe werk na 'n kontaksessie met 'n dosent moet bring. Studente is blykbaar deurgaans hardwerkend, moontlik 'n gevolg van die geweldig hoë toelatingsvereistes. In 'n tien-week akademiese program lewer studente gewoonlik ongeveer 16 geskrewe werkstukke (verdeel tussen die twee onderafdelings van 'n vak wat die gewone studielading uitmaak) in.

Latyn op skool word erg geraak deur dieselfde sosiale faktore wat in Suid-Afrika geld en in staatsondersteunde skole kwyn dit steeds. Die sogenaamde "independent schools" het egter nog goeie inskrywings. 'n Innovasie is die erkenning van die noodsaaklikheid van "afstandsonderrig": hierin voorsien die nuwe "Selfstudie-handleiding" van die CLC. Eksaminering van Latyn op skoolvlak is onderworpe aan dieselfde spanninge wat tans die hele sekondere veld byna lamle.

Tydens my besoek was die hele Engeland in rep en roer oor ' $n$ imminente staking deur leerkragte, omdat die staat eensydig 'n byna onuitvoerbare sisteem van 4 openbare eksamens (per leerling) wil implementeer. Blykbaar is daar te veel burokrate wat in die opstel van die toetse tussenby tree. 'n Soortgelyke voorbeeld is die toets vir Latyn, opgestel deur ' $n$ komitee van kenners, wat sonder hul medewete gesnoei is deur 'n "gesaghebbende" wat glad nie die taal ken nie.

\section{J.M. Claassen}

